\title{
Geochemical interactions between hydraulic fracturing fluid and fractured Whitby Mudstone
}

\author{
John Kaszuba ${ }^{1, *}$, Maartje E. Houben ${ }^{2}$, and Suzanne J.T. Hangx ${ }^{2}$ \\ ${ }^{1}$ Department of Geology \& Geophysics and School of Energy Resources, 1000 E. University Ave., \\ University of Wyoming, Laramie, Wyoming 82071 USA \\ ${ }^{2}$ Department of Earth Sciences, Utrecht University, Budapestlaan 4, 3584 CD Utrecht, The \\ Netherlands
}

\begin{abstract}
We examine how a mechanically-induced fracture network may influence geochemical reaction between shale and stimulation fluid used in hydraulic fracturing. Two different types of bedding-parallel fractures, a simple fracture between bedding planes and a damage zone with multiple fractures, were induced in the Whitby Mudstone (Early Jurassic) from the UK. Both fractured shales were subsequently reacted with stimulation fluid at $10 \mathrm{MPa}$ and $100^{\circ} \mathrm{C}$ for about 2000 hours. $\mathrm{pH}$ increased from 2.1 to about 6 after 1000 hours of reaction in both shales, but $\mathrm{pH}$ increased slightly more rapidly by reaction in the shale with the damage zone. Total dissolved inorganic carbon evolved in similar fashion in both experiments and did not readily distinguish between the two styles of fracturing induced in the Whitby Mudstone.
\end{abstract}

\section{Introduction}

Interest in shale has grown with the advent of new techniques to extract hydrocarbons from these rocks. Development of unconventional shale oil and gas reservoirs by 'hydraulic fracking' combines chemical and mechanical stimulation with new technologies for drilling horizontal wells that extend for hundreds to thousands of meters within organicrich beds. Stimulation fluids, a mixture of water and chemical additives, are injected into these horizontal wells at pressures that propagate fractures into adjoining beds.

Chemical imbalance between the shale and injected fluids potentially drives geochemical reactions that may alter mechanical properties of the rock. At the same time, fracturing may drive physical changes that alter geochemical reaction paths of water-rock interactions. Coupling and feedback mechanisms between geochemistry and geomechanics are poorly understood in rocks in general, let alone in shales. Here we examine one small aspect of the problem, how a mechanically-induced fracture network may influence geochemical reaction between stimulation fluid and shale. We investigate two different types of bedding-parallel fractures, a simple fracture along bedding and a damage zone imposed by direct shear parallel to bedding. Our shale of interest is the Early Jurassic Whitby Mudstone from the UK; the Whitby Mudstone is the time equivalent of the

\footnotetext{
*Corresponding author: john.kaszuba@uwyo.edu
} 
Posidonia Shale, one of the main hydrocarbon source rocks in the North Sea [1] . Both shales are potential unconventional oil and gas resources in Northern Europe [2, 3]. In this short paper, we present preliminary results for this chemo-mechanical study on fractures in shale.

\section{Methods}

\subsection{Experimental approach}

The permeability of two cores of Whitby Mudstone was measured before and after inducing fractures. Each fractured core was subsequently reacted at $10 \mathrm{MPa}$ and $100^{\circ} \mathrm{C}$ with a simplified stimulation fluid created in the laboratory; the stimulation fluid was periodically sampled to monitor reaction progress. Permeability is being measured and microstructures are being evaluated for both reacted cores. Total dissolved inorganic carbon (DIC) and $\mathrm{pH}$ were determined for the fluid samples, and major, minor, and trace element geochemistry is being analyzed.

\subsection{Starting materials}

Shale samples were collected from an organic matter-rich outcrop of the Whitby Mudstone, the bottom eight meters of the Mulgrave Shale member, located along the coast near Port Mulgrave (UK) [4]. The Mulgrave Shale member consists of fissile, bituminous, dark grey mudstone with TOC values of $4-15 \%$. The samples were packed into plastic boxes filled with seawater to keep the samples wet during transportation and storage. This approach prevented the shale from drying out, which could have caused issues when drilling the cores. Two cores of the shale, $2.5 \mathrm{~cm}$ in diameter and $31-43 \mathrm{~mm}$ in length, were drilled parallel to bedding (Figure 1).

The chemistry of the stimulation fluid was based on the composition of fluids used in hydraulic fracking of shales in the Rocky Mountain region of the US [5]. The fluid was an acidic ( $\mathrm{pH}=2.1), \mathrm{NaCl}$ water (ionic strength $=0.07 \mathrm{~mol} / \mathrm{kg}$ ) containing $\mathrm{Ca}, \mathrm{Mg}, \mathrm{HCO}_{3}{ }^{-}$, and $\mathrm{SO}_{4}{ }^{2-}$ in $\mathrm{mmol} / \mathrm{kg}$ quantities. Two chemicals commonly used in hydraulic fracking fluids were added to the water, $\mathrm{KCl}(10 \mathrm{mmol} / \mathrm{kg})$ as a clay stabilizer and acetic acid $(3.3 \mathrm{mmol} / \mathrm{kg})$ to inhibit precipitation of Fe oxyhydroxides. Cs (1 $\mathrm{mmol} / \mathrm{kg}$ ) was also added to enhance imaging of

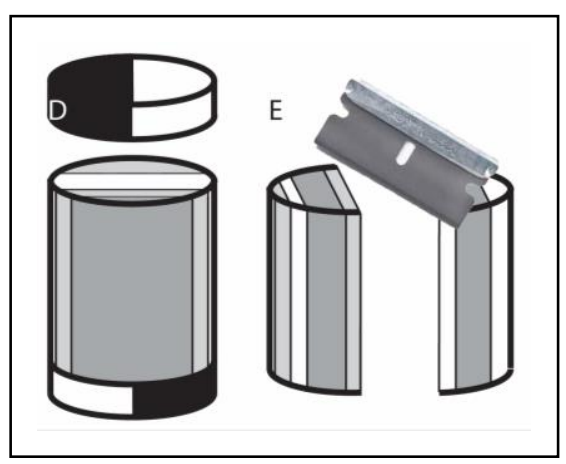

Fig. 1. Schematic drawing of the mechanical experimental direct shear setup showing the sample and the stainless steel-Teflon semi cylinder assembly (image D). Image $\mathrm{D}$ indicates the direct shear direction with respect to bedding and image $\mathrm{E}$ indicates induced fracturing along one bedding plane. fluid penetration into the fractures.

\subsection{Mechanical experiments and permeability measurements}

One shale core was fractured along the bedding plane by applying force with a razor blade (Figure 1). This fractured shale was then wrapped in a teflon sleeve for subsequent handling and analysis. To fracture the second core, a direct shear experiment was performed using a 
conventional triaxial deformation apparatus at Utrecht University [6]. To facilitate the formation of bedding-parallel fractures, two steel-Teflon semi-cylinder assemblies were placed between the end pistons and the sample [7]. The experiment was performed dry and at room temperature, at a confining pressure of $30 \mathrm{MPa}$ and an axial strain rate of $\sim 10^{-5} \mathrm{~s}^{-1}$. Axial stress was increased until failure occurred, as indicated by a loss of differential stress across the sample.

Argon-gas permeametry was used at Utrecht University to measure the gas permeability of both fractured samples, making use of the pressure step decay method [8-10]. Permeability was measured up to confining pressures of $30 \mathrm{MPa}$ and pore pressures used were $2 \mathrm{MPa}$ using Ar gas as pore fluid. The Teflon sleeves of both fractured samples were notched after the permeability experiments to enhance fluid penetration in subsequent geochemical experiments.

\subsection{Geochemical experiments}

Two experiments (one for each fractured shale) were conducted in rocking furnace-pressure vessel assemblies - also known as rocker bombs - at the University of Wyoming using methods established for hydrothermal experiments [11, 12]. Stimulation fluid and shale were combined in a Au reaction cell at a water-rock ration of 3.2:1 to emulate the volume of fluids relative to the surface area of rocks exposed in millimeter-scale fractures [13]. The cell was subsequently sealed, pressurized to $10 \mathrm{MPa}$, and heated to $100^{\circ} \mathrm{C}$. Experiments were conducted for $\sim 2000$ hours ( 83 days), longer than the typical duration (30 days) between the onset of hydraulic fracturing and the time the well is opened for fluid production, to maximize reactivity. Aqueous samples were periodically collected from the experiments to quantify the evolution of in-situ fluid chemistry.

\section{Results and discussion}

Multiple fractures formed in the shale that was subjected to direct shear parallel to bedding (Figure 2). Damage zones developed between the fractures; these zones are less cohesive than the undamaged matrix. Quartz and carbonate grains are broken and micas tended to bend into the main fracture. Clay minerals in the undeformed shale are less than $2 \mu \mathrm{m}$ in size, making it difficult to determine how these minerals responded to the deformation.

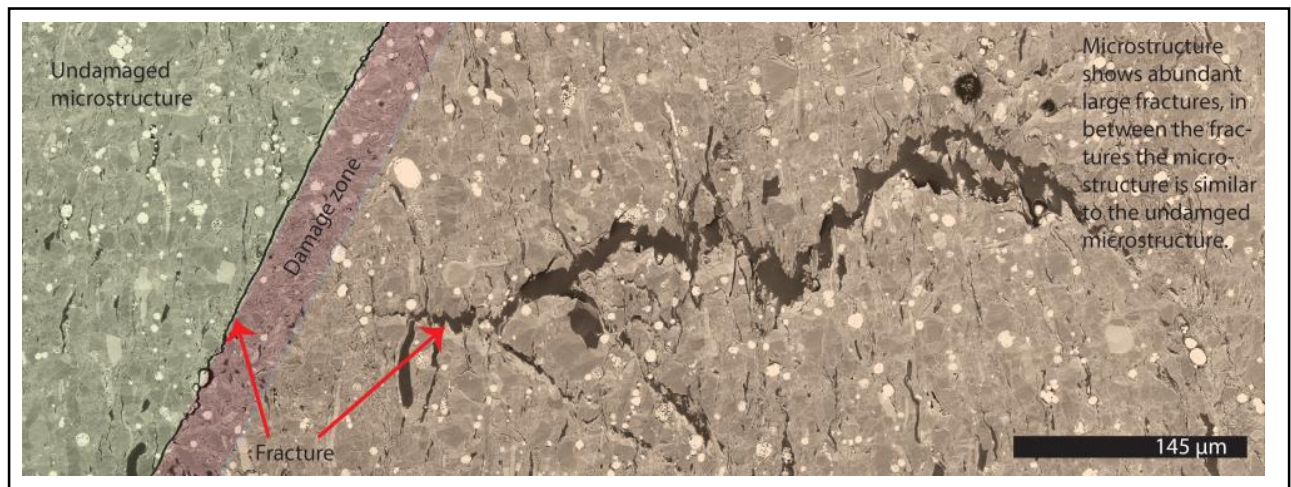

Fig. 2. SEM image of shale fractured by direct shear in the triaxial deformation apparatus. The shale used in the geochemical experiments was fractured by the same experimental setup as the shale pictured here. The microstructure shows abundant large fractures; in between the fractures the microstructure is similar to the microstructure of undamaged shale. 
After 136 hours of reaction between shale and stimulation fluid, $\mathrm{pH}$ increased from the initial value of 2.1 to 4.4 in the experiment with the simple fracture and to 4.7 in the experiment with shale that was fractured by direct shear (Figure 3). In both geochemical experiments, pH subsequently increased to about 5.7 after a total of 468 hours of reaction and to 6 after a total of 1000 hours of reaction; $\mathrm{pH}$ remained at about 6 for the remaining 1000 hours of both experiments. Total DIC in both experiments evolved in similar fashion. Total DIC as $\mathrm{CO}_{2}(\mathrm{aq})$ increased from an initial value of $43 \mathrm{ppm}$ to about $560 \mathrm{ppm}$ after approximately 1000 hours of reaction and remained at about this concentration for the remaining 1000 hours of both experiments.
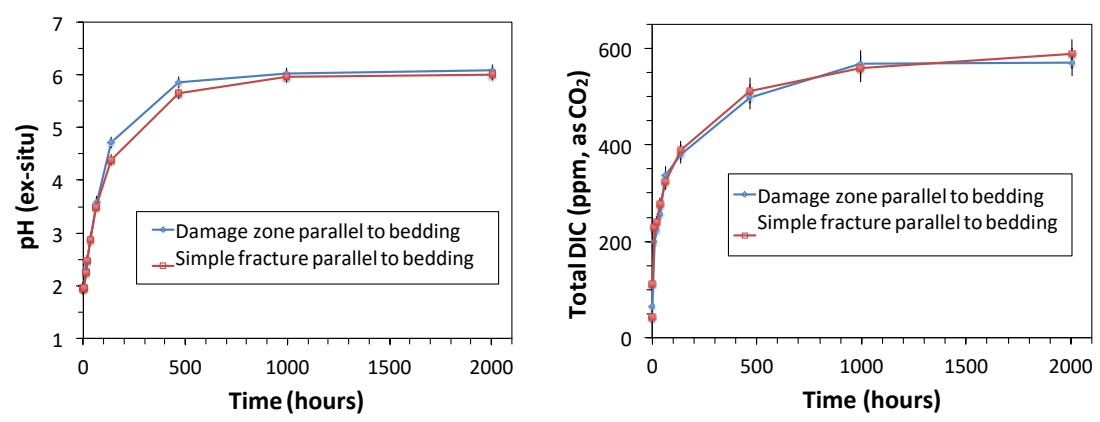

Fig. 3. Geochemical evolution of $\mathrm{pH}$ and total dissolved inorganic carbon (DIC) as $\mathrm{CO}_{2}(\mathrm{aq})$.

\section{Conclusions}

Two different bedding-parallel fractures were induced in Whitby Mudstone, a single fracture along one bedding plane and multiple fractures in response to direct shear. In the latter, a damage zone formed between the multiple fractures; this zone is less cohesive than undamaged matrix. Reaction of stimulation fluid at reservoir conditions (10 $\mathrm{MPa}$ and $100^{\circ} \mathrm{C}$ ) with both shales increased $\mathrm{pH}$ from 2.1 to $\sim 6$ after 1000 hours; $\mathrm{pH}$ increased slightly more rapidly by reaction with the damage zone. Total DIC as $\mathrm{CO}_{2}(\mathrm{aq})$ evolved in similar fashion in both experiments, from $43 \mathrm{ppm}$ to $\sim 560 \mathrm{ppm}$. $\mathrm{pH}$ might be useful to track initial water-rock interactions between stimulation fluid and shale, but DIC did not distinguish between the two styles of fractures induced in the Whitby Mudstone.

Kaszuba's work was supported by the University of Wyoming School of Energy Resources and a Nielson Energy Fellowship. Houben is supported by the Netherlands Organisation for Scientific Research through a VENI grant (NWO; 016.Veni.171.041).

\section{References}

1. R. Herber, J. de Jager, Netherlands Jour. of Geosc., 89-2, 119-135 (2010)

2. M. Zijp, J. ten Veen, R. Verreussel, L. van Laerhoven, T. Boxem, Society Petrol. Eng., 167736, (2014)

3. J. ter Heege, M. Zijp, S. Nelskamp, L. Douma, R. Verreussel, J. ten Veen, G. de Bruin, R. Peters, J. Nat. Gas Sci. Eng., 27, 558-577 (2015)

4. M.E. Houben, A. Barnhoorn, J. Lie-A-Fat, T. Ravestein, C.J. Peach, M.R. Drury, Mar. Pet. Geol., 70, 185-200 (2016) 
5. U.S. Environmental Protection Agency, Analysis of Hydraulic Fracturing Fluid Data from the FracFocus Chemical Disclosure Registry 1.0. Office of Research and Development, Washington, D.C. EPA/601/R-14/003 (2015)

6. S.J.T. Hangx, C.J. Spiers, C.J. Peach, Geofluids, 10, 369-387 (2010)

7. J.W. Carey, Z. Lei, E. Rougier, H. Mori, H. Viswanathan, J. Unconv. Oil Gas Resour., 11, 27-43 (2015)

8. H.J. Sutherland, S.P. Cave, Int. J. Rock Mech. Min. Sci., 17, 281-288 (1980)

9. C.J. Peach, C.J. Spiers, Tectonophysics, 256, 101-128 (1996)

10. X. Cui, A.M.M. Bustin, R.M. Bustin, Geofluids, 9, 208-223 (2009)

11. J.P. Kaszuba, D.R. Janecky, M.G. Snow, Appl. Geochem., 18, 1065-1080 (2003)

12. W.E. Seyfried, Jr., D.R. Janecky, M.E. Berndt, in: G.C. Ulmer, H.L. Barnes (Eds.) Hydroth. Exper. Tech., John Wiley \& Sons, New York, pp. 216-239 (1987)

13. D. O'Malley, S. Karra, R.P. Currier, N. Makedonska, J.D. Hyman, H.S. Viswanathan, Groundwater, 54, 488-497 (2016) 